\title{
บusisersaly
}

\section{Community, consumerism and credit: the experience of an urban community in North- West Ireland}

Manktelow, R. (2011). Community, consumerism and credit: the experience of an urban community in NorthWest Ireland. Community, Work and Family, 14(3), 257-274. https://doi.org/10.1080/13668803.2010.520839

Link to publication record in Ulster University Research Portal

\section{Published in:}

Community, Work and Family

Publication Status:

Published (in print/issue): 25/03/2011

DOI:

10.1080/13668803.2010.520839

\section{Document Version}

Publisher's PDF, also known as Version of record

\section{General rights}

Copyright for the publications made accessible via Ulster University's Research Portal is retained by the author(s) and / or other copyright owners and it is a condition of accessing these publications that users recognise and abide by the legal requirements associated with these rights.

\section{Take down policy}

The Research Portal is Ulster University's institutional repository that provides access to Ulster's research outputs. Every effort has been made to ensure that content in the Research Portal does not infringe any person's rights, or applicable UK laws. If you discover content in the Research Portal that you believe breaches copyright or violates any law, please contact pure-support@ulster.ac.uk. 
This article was downloaded by: [University of Ulster]

On: 30 March 2011

Access details: Access Details: [subscription number 773566367]

Publisher Routledge

Informa Ltd Registered in England and Wales Registered Number: 1072954 Registered office: Mortimer House, 3741 Mortimer Street, London W1T 3JH, UK

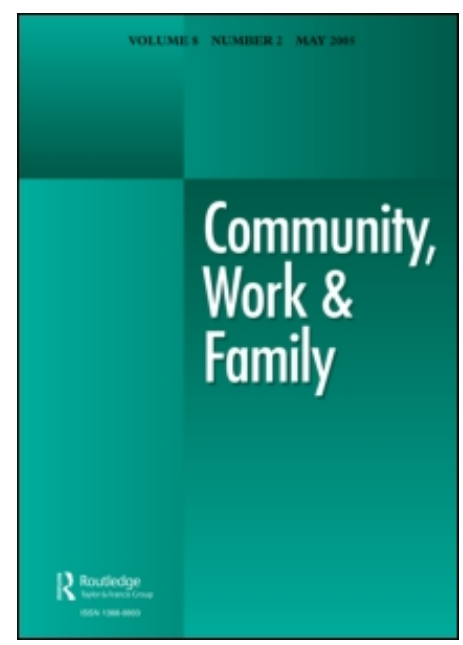

\section{Community, Work \& Family}

Publication details, including instructions for authors and subscription information:

http://www.informaworld.com/smpp/title content=t713412097

Community, consumerism and credit: the experience of an urban community in North-West Ireland

Roger Manktelow ${ }^{\mathrm{a}}$

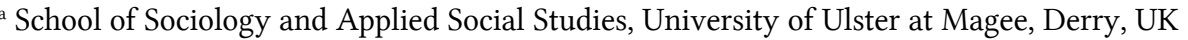

First published on: 25 March 2011

To cite this Article Manktelow, Roger(2011) 'Community, consumerism and credit: the experience of an urban community in North-West Ireland', Community, Work \& Family,, First published on: 25 March 2011 (iFirst)

To link to this Article: DOI: $10.1080 / 13668803.2010 .520839$

URL: http://dx.doi.org/10.1080/13668803.2010.520839

\section{PLEASE SCROLL DOWN FOR ARTICLE}

Full terms and conditions of use: http://www.informaworld.com/terms-and-conditions-of-access.pdf

This article may be used for research, teaching and private study purposes. Any substantial or systematic reproduction, re-distribution, re-selling, loan or sub-licensing, systematic supply or distribution in any form to anyone is expressly forbidden.

The publisher does not give any warranty express or implied or make any representation that the contents will be complete or accurate or up to date. The accuracy of any instructions, formulae and drug doses should be independently verified with primary sources. The publisher shall not be liable for any loss, actions, claims, proceedings, demand or costs or damages whatsoever or howsoever caused arising directly or indirectly in connection with or arising out of the use of this material. 


\title{
Community, consumerism and credit: the experience of an urban community in North-West Ireland
}

\author{
Roger Manktelow*
}

School of Sociology and Applied Social Studies, University of Ulster at Magee, Derry, BT48 7JL, UK

(Received 9 July 2008; final version received 13 November 2009)

The problems of debt and consumerism are global phenomena. Although credit has become widely available, it is an iniquitous paradox that those most in need (those dependent on low wages or state benefits) pay substantially more for their credit than the better-off. The study focuses on how forces that operate at a global level - consumerism and the international monetary system - impact on small local communities, in this case, a relatively deprived, urban, public housing estate in the City of Derry, Northern Ireland.

The community is traditional and cohesive with horizontal bonds of extended kinship-helping networks of reciprocity and interdependence, culturally homogeneous with a strong sense of identity - Catholic, working class and nationalist; and spatially defined - post-conflict segregated and geographically immobile. The community can be characterised as having strong links of shared communitarian values and informal systems of mutual aid, on the one hand, and weak ties into the wider world producing a sense of insularity, isolation and stagnation, on the other.

The impact of debt and consumerism in the community was investigated using a series of focus groups held with representatives of key constituencies - women, teenagers, children and older people. Five key themes were generated from a process of categorical analysis of the focus-group data; these themes described the consumerist pressures and reported the financial struggles and resulting threat to well-being. The constituent groups of the local community reported a diverse experience of strain, isolation, powerlessness and guilt. Their experience of consumerism was age-differentiated and their choice of contemporary status markers was made within the cultural context of the local community. These markers included both iconic acquisitions and rituals of ceremonial celebration First Holy Communion, Halloween, Christmas and St. Patrick's Day - occasions which provided key opportunities for conspicuous consumption.

The study was concerned to generate a sense of how local community action might effectively tackle such powerful global forces of consumerism and the multinational credit industry. Such an intervention might include education on financial and media literacy, money management and debt advice services, consciousness-raising anti-consumerist workshops, programmes of personal development and an agenda for political action.

Keywords: community; consumerism; credit

Les problèmes de la dette de la consumérisme sont des phénomènes mondials. Bien que le crédit est devenu disposable librement, c'est un paradoxe mauvais que

\footnotetext{
*Email: r.manktelow@ulster.ac.uk
} 
ceux-là qui sont le plus dependent (ceux qui dépendent de paye le plus bas ou les allocations d'état) payent plus leur credit que les riches. L'étude examine comment les forces qui travaillent mondialement - la consumérisme et le systèm internationale de monnaie - affectent des petites communautés locales, en cet cas, un banlieu touché par le sous-emploi dans le cité de Derry en Nord Irelande.

La communauté est traditionale et très unie avec des liens horizontals de parenté - des réseaux de secours, réciproque et interdependent, homogène avec un sens fort de son identité - Catholique, nationaliste et ouvrier; et spatialent determine - ou la segregation religeuse est en vigueur après la conflit avec l'immobilité géographique. La communauté s'est characterise par des liens forts des valeurs communautariennes et des systèms offiieux mutuels d'aide, d'une part, et, d'autres part, des liens faibles à le monde extérieur qui provoquent un sens d'étroitesse d'esprit, d'isolement et de la stagnation.

La chercheur a examiné l'impact sur la communauté de la dette et de la consumérisme avec un série des groupes essentielles se composent des femmes, des adolescents, des jeunes et des personnes âgées. Les données s'analysaient catégoriquement et ils ont rendu cinque thèmes principals; ces thèmes decrirent les pressions a consommer et le lutte financière et le danger resultant pour l'état mental. Les groupes différentes du quartier ont transmis un expérience divers de la tension nerveuse, l'isolement, l'impuissance et un sentiment de la culpabilité. L'expérience de la consumérisme était complètement différent entre les tranches d'âges et ils faisaient leur choix de symbols de prestige dans la contexte de la communauté. Ces symbols de prestige se composaient d'acquisitions de consummations ostentatoires et des rituals de celebrations - le baptême, la première communion, Halloween, le Noël et la fète du Patrick.

L'étude a traité de la question: comment la communauté peut efficacement s'attaque aux forces forts et mondials de consumérisme et l'industrie multinationale du credit. C'est possible que ces interventions continent les instructions en comment gérier d'argent et utiliser, le développement des services consultatifs de dette, des ateliers consacres au flaux de consumérisme, des programmes de l'amélioration personnelle et un manifeste politique.

Mots-clés: La communauté; la consumérisme; le crédit

\section{Introduction}

During the 10-year period from 1997 to 2007, the British economy underwent profound change. Consumer debt in the UK increased at a rate of over $10 \%$ per annum from a figure of $£ 570$ billion in 1997 to $£ 1517$ billion in 2007, with Britain accounting for one half of total European credit-card debt and having higher levels of personal-sector debt in relation to disposable income than any other industrialised country (Turner, 2008). This credit explosion was driven by a speculative property asset bubble in which housing prices more than doubled. Widespread borrowing at super-low interest rates was encouraged against the expectation of continuing rising house prices.

The unravelling of Britain's overindebtedness first came to the UK public consciousness with the run on deposits, government guarantee and subsequent nationalisation of the Northern Rock Bank in February, 2008. On a global level, the collapse and bankruptcy of the New York investment bank, Lehman Brothers, 6 months later, caused paralysis in the international capital markets threatening the collapse of banks throughout the world. Unemployment rose rapidly, house prices fell and boom turned to bust (Turner, 2010).

In order to ensure the survival of the British banking system and the City of London, there followed government majority shareholding of the Royal Bank of 
Scotland and minority shareholding in Lloyds Banking Group. In an effort to avoid spiralling economic contraction and debt deflation, the Bank of England reduced interest rates to minimum levels, indulged in quantitative easing to expand the money supply and avoid debt deflation, and devalued sterling to promote the export of British manufactured goods.

It is suggested that there were three chief causes of the credit explosion and the subsequent credit crash. The first was the abandonment of financial regulation from 1986 which allowed banks to conceal high-risk sub-prime lending in mortgagebacked securities, collaterised debt obligations, credit default swaps and structured investment vehicles. The operation of a Ponzi scheme by New York financier, Bernie Madoff, undiscovered for many years, which robbed investors of 150 billion dollars, is just one example of the consequences of absent or 'light touch' regulation. Public opinion has been outraged at the cost to the taxpayer of bailing-out the banks and has demanded tighter financial controls, an end to the bankers' bonus culture and higher capital tier one holdings by the banks.

A second cause was the systematic dismantling of labour protection in the 1980s and government sponsorship of unbridled free trade. Such factors encouraged multinational corporations to relocate for cheaper labour, driving down wages and reducing consumer demand. In the UK, as a result of companies moving offshore, one third of manufacturing jobs were lost prompting an over-reliance on bubble jobs in an inflated financial sector (Turner, 2008).

The third cause was the trading imbalances in the global economy with states such as China and the major oil-producing countries, such as the Gulf States, enjoying massive trading surpluses. Such national wealth in the form of state sovereign wealth funds was invested in the USA, Britain and other debtor countries where savings were low and debt was high. This international transfer of wealth enabled American and British consumers to fund their consumer debt and maintain their high levels of consumer spending.

The starting point of the present study is the conceptualisation of contemporary community development as 'to think global, but to act local' (Powell \& Geoghegan, 2004). The study addresses the two questions: how are such global forces of credit and consumerism experienced at the local level and what local collective strategies can be developed to counter such forces? The study was conducted in an urban, relatively deprived community of public housing in collaboration with the local community partnership and was funded by a central government-funded initiative to reduce health inequalities (Western Health Action Zone - WHAZ).

\section{Consumerism}

Credit is the driver of consumerism and economic growth and credit cards give people the opportunity to undertake consumption that otherwise would not take place (Ritzer, 1995). The cognitive connection between household earnings and consumption decisions has been broken by mass marketing campaigns promoting easy credit (Manning, 2002). No longer is the dominant ethos one of the Victorian virtues expounded by Samuel Smiles of 'neither a lender or a borrower be' and 'look after the pennies and the pounds will look after themselves'. Neither does the stigma of incarceration in the Marshalsea, the debtors' prison, await those who have been improvident, as vividly described by Dickens in Little Dorritt; indeed, following the 
11 September bombing of the New York Twin Towers in 2001, Americans were urged to do their patriotic duty to 'shop till they drop' (Berger, 2004) in order to keep the American economy afloat.

Even though real incomes have trebled over the last 50 years, $60 \%$ of Britons feel that they cannot afford to buy everything that they really need (Kempson, 2002). Schor (1998) reports that in America the gap between aspirational incomes, the income necessary to achieve the lifestyle aspired to, and real incomes has widened and Americans have taken on record levels of debt to bridge this gap. Clearly, the pressure to consume is limitless as needs are scaled up in the desire to emulate the very rich and their celebrity lifestyles. This phenomenon can be observed in our evolving definition of what constitutes poverty. The Economics and Social Research Institute (ESRI) now identifies 11 proxy indicators in their poverty definition which include having friends or family for a drink or meal once a month, going out for entertainment in the past fortnight and buying presents for family or friends (Whelan, 2006). Of course, the extent to which choices between different lifestyles can be made is dependent on income and, as Veblen (1953) recognised, many years ago, conspicuous consumption is a means to reinforce inequalities.

Consumerism has become the key idea of the age as the way to achieve happiness with the status of personhood being actualised by becoming a consumer (Goldman \& Papson, 1998). However, as Cahill (1998) states: 'the economic system of production and consumption that underpins this notion of happiness is bought at a high cost'. Consumerism has been blamed for destroying traditional cultures and solidarities and engendering a sense of alienation as a natural response to the hopelessness of modern consumer life. In a consumerist society, the consumer's duty is to exercise choice but consumption is an activity which is individual and solitary. The rich can signify their wealth by visible displays of extravagant consumption and the consumerist culture is promoted by a bombardment of glossy commercials (Paterson, 2006). However, the poor, whilst they inhabit this same consumerist culture, are cut off from this 'happy life' and left behind, degraded and humiliated as inadequate or 'flawed' consumers (Bauman, 1998).

Wilkinson and Pickett (2009) argue that these permanently raised consumerist expectations play a key role in the creation of health inequalities in hierarchical, developed societies. It has been established that in developed countries health is related less to people's absolute living standards as it is to their position in society, as expressed by their income. Low social status causes adverse psychosocial effects feelings of shame, inferiority, subordination and incompetence (James, 2008). In a consumerist culture, when low-income individuals make adverse social comparisons with other social groups they experience poor confidence, insecurity, inadequacy, embarrassment and even humiliation. Furthermore, social isolation may follow and, as friendships and social networks atrophy, individuals feel increasingly vulnerable to the way they are seen by others.

It is recognised that children play a key role in the consumerist society. Marketing agencies court children because of their influence on family purchases and adult spending patterns, and peer pressure and parental guilt force parents to purchase what they cannot really afford. Less dependent on adults to learn about consumer values, children are targeted by mass advertising because they are important influencers of their parents' consumption. As parents' income has increased, educational levels raised, double-income families the norm and parent-child 
relationships liberalised, children now influence daily household purchases and parents' choice of restaurant, holiday destination and car ownership (Gunter \& Furnham, 1998).

Brand awareness is sown early in young children through the use of children's favourite television characters in blanket advertising of a variety of goods. Schor (2004) has shown that, by 18 months, babies can recognise logos, that, during their nursery school years, children will request an average of 25 products a day, that, by the time children enter primary school, the average child can identify 200 logos, and that children between the ages of 6 and 12 spend more time shopping than reading, attending youth groups, playing outdoors or spending time in household conversation. Nine- to 12-year olds possess a strong sense of commitment and loyalty to their peer group, are acutely sensitive to what is 'cool' and what is 'in', and are alert to avoiding being ridiculed about what they wear and watch on television (Valkenburg \& Cantor, 2001). Shopping is now a major social practice and the second most popular leisure activity in Britain, after watching television (National Statistics Office, 2001). Shopping malls and shopping centres have become key public spaces to 'hang around' in, especially for youth and, as a consequence, there has been a collapse in the corner shop of the participatory community.

\section{The poor pay more}

Consumer credit is generally used for two purposes: to finance consumerism for those on middle and higher incomes and to pay for essentials for those on low incomes. Different tiers of the credit industry are used for these very different purposes. The first tier is composed of mainstream lenders such as banks and building societies which focus on higher-income households who budget by the month, have a bank account and spend a significant proportion of their income on consumer goods.

The second tier of the credit industry is made up of high interest fringe agencies, such as mail order companies, doorstep lenders and check traders which are for legal purposes generally referred to as 'moneylenders'. Such companies can trade legally providing they have a licence from the appropriate regulatory authority (the Office of Fair Trading in Northern Ireland) and their interest rates are regulated to some extent. There are also unlicensed moneylenders, often described as 'loan sharks', who charge colossal interest rates and operate outside the law (Northern Ireland Association of Citizens Advice Bureaux [NICAB], 2001).

Moneylenders are willing to lend to borrowers unable to obtain credit from mainstream lenders because of low income, adverse credit rating and unemployment. It is estimated that one in five UK borrowers is denied access to mainstream credit from banks, building societies and finance houses (Collard, Kempson, \& Dominy, 2003). These borrowers are poor people who pay the most for their credit whilst being the least able to afford it. Poor people use credit in quite small quantities in order to cope with money management problems caused by lump-sum purchases such as clothing and durable household goods (Ford, 1991). They budget by the week, do not have a bank account and, for one in eight households, run out of money before the end of the week (Berthoud, 1989).

The use of moneylenders in the Republic of Ireland has been found to be most common amongst lone parents pushed into using unsanctioned and more expensive 
credit after being refused access to mainstream financial services (OPEN, 2005). Loans of instant cash may be secured against family possessions - a television set, a social-security book or a home. Such lending has often been criticised for its predatory nature and for the huge interest charged, sometimes from 500 to $1000 \%$ (Palmer \& Conaty, 2002). However, an alternative viewpoint has been put forward in a recent study, which compared the use of moneylenders and credit unions and saw some advantages in the former in terms of their willingness to provide small loans quickly and easily in emergency circumstances to individuals with no saving history (Byrne, McCarthy, \& Ward, 2005).

High annual percentage rates (APRs) of interest are not the only problem as credit agreements often carry complex clauses, which allow the lender to increase dramatically its charges if a repayment is missed. During the credit explosion, people on lower incomes were approved for loans which they would not have received previously. At the time, this sub-prime lending was highly profitable for credit agencies. Households with an annual income of less than $£ 11,500$ owed $430 \%$ of their incomes as compared with those earning more than $£ 50,000$ owing $107 \%$ of their income (Their profit, 2006).

It has been found that the younger and poorer households are, the greater is their likelihood of being in financial difficulty. Families with two and three children are four and five times more likely to be behind with repayments than childless adults of the same age (Berthoud, 1989). Those most likely to be in debt are non-working, lone parents. Households headed either by part-time workers or by people unable to work through long-term sickness or disability are also more likely to be in debt. Many social-security claimants are in debt because of their low income. Indebtedness in low-income households is not due to excessive consumerism but week-to-week budgeting on an income inadequate to meet the needs of the household.

A study on poverty in Derry, Northern Ireland revealed that $70 \%$ of families reported some form of debt with lone parents being most at risk, and that lowerincome groups relied most heavily on social fund loans ( $41 \%$ of families surveyed and average size of loan, $£ 314)$, followed by mail order $(39 \%)$ and the credit union $(38 \%)$. The study also found that poorer families worried more abut being in debt, exhibited signs of stress and anxiety caused by difficulties in repaying loans and reported poorer physical health. Subjective feelings of stress resulting from debt were more predictive of poor physical and mental health than social circumstances or debt per se (Mallett, 2002).

\section{The study}

\section{The community setting}

The chief feature of the city of Derry is its peripherality. Spatially, it is located on the margin of the province of Northern Ireland, in the north-west corner of the island of Ireland and at the furthest western distance from the hub of the European Union. Economically, one hundred years ago, Derry was a world leader in shirt manufacturing but its traditional industries are now gone hastened by the global search for cheap labour and today the city has one of the highest rates of unemployment in Northern Ireland (Mitchell, 1992). Politically, following the Partition of Ireland in 1921 there was a history of discrimination and gerrymandering by the Northern Ireland 
Stormont Government in favour of the local unionist minority and an absence of local government investment (McCann, 1984). Culturally, the city is characterised by bi-culturism and is divided between the Protestant and loyalist Waterside east bank of the River Foyle and the Catholic and nationalist Cityside west bank.

All these factors came together in 1966 when the Stormont decision not to locate the second university of Northern Ireland in Derry resulted in a widespread crosscommunity protest. It has been said that the Troubles began in Derry at that time (Lacey, 1999). The grievances of the Derry working class led to demands for civil rights which were taken up across Northern Ireland. Derry suffered in the Troubles in many ways. But, it may be argued that there was less evident sectarianism and, therefore, the consequences of the conflict were not as great as elsewhere in the North because of the greater tolerance of the other side's point of view (Manktelow, 2007).

Derry has been characterised by long-term structural unemployment, inadequate housing and poverty (McCann, 1984) resulting in high emigration particularly to the conurbations of Scotland and Northern England. This economic history is of importance in shaping a workforce today that has a tradition of female employment and factory working. However, the heritage of adversity has had a positive side: to counter the effects of unemployment, politics based on class rather than religious affiliation were espoused; the experience of emigration meant that Derry had a greater proportion of its population who had lived and worked outside of Northern Ireland; and the lack of state services resulted in a strong community spirit of selfhelp and community action.

Derry is the third most deprived district in Northern Ireland with a high rate of unemployment and a high dependency on state benefit, in particular Income Support, Disabled Living Allowance and Working Family Tax Credits. Proportionately, the city now has the youngest population of any district in the UK (Gallaher, 2001). The rates of psychiatric disorder in Derry have been found to be even higher than deprived inner-city area of London with depression greater than the national average and concentrated in women, substance misuse in men and a high prevalence of anxiety which remained untreated (McConnell, Bebbington, McLelland, Gillespie, \& Houghton, 2002).

The location of the study was an urban community of public housing located in the Derry City Council area with an urban and Irish culture which values socialising, hospitality, generosity and large and close families. The community is traditional and cohesive with horizontal bonds of extended kinship-helping networks of reciprocity and interdependence, culturally homogeneous with a strong sense of identity Catholic, working class and nationalist and spatially defined - a local population which is post-conflict segregated and geographically immobile (Donnan \& McFarlane, 1986). It has been argued that the nationalist and Catholic culture has become more visible because of the confidence of the nationalist community engendered by the peace secured by the 1998 Good Friday Agreement (Elliott, 2000). The community can be characterised as having strong links of shared communitarian values and informal systems of mutual aid, on the one hand, and weak ties into the wider world producing a sense of insularity, isolation and stagnation, on the other (Granovetter, 1973).

The area is in the top $10 \%$ of most deprived wards in Northern Ireland in terms of dependence on social security and economic inactivity. Eighty-five per cent of households receive housing benefit, $76 \%$ are in receipt of Income Support, over 
$35 \%$ of the male population are unemployed and there are 559 lone parents in the locality. The proportion of owner occupation is approximately one quarter of the local housing stock of almost 1200 dwellings. A health survey of the area revealed high self-reported levels of feelings of depression (38\%), anxiety (31\%), post-natal depression (33\%) and child developmental and behavioural difficulties (29\%). Stress was endemic in the local community with more than three quarters of the local sample admitting to having suffered from it and two thirds attributing it to money worries (B\&HCDP, 2002).

Within the local area, there is a wealth of local community activity with some 20 active locally based groups committed to effecting positive change. These include a Lifestart programme for pre-school children with special needs, an outreach office of the Citizen's Advice Bureau opened one morning a week, and a Sure Start scheme providing play and pre-education provision for the under fives aimed at freeing mothers for employment training (Manktelow \& Lindsay, 2003). The Parish (Catholic Church) operates a Savings Scheme which provides a convenient opportunity for families to save small amounts for major spending occasions, a total of $£ 600,000$ was saved for Christmas 2004. There is also a local Chapter of the Society of St. Vincent de Paul, a parish-based organisation of Catholic lay visitors who consider requests from families for emergency monetary help. A web of informal reciprocal borrowing also exists in the nature of 'gift relations' which reinforce the traditional values of community in Ireland - the home and the family (Keohane \& Kuhling, 2004).

\section{Methodology}

A Research Steering Group, consisting of two members of the local community association, a funder representative, the Community Health Visitor, the local Social Security Agency manager and the researcher agreed research aim and methodology. The research aim was to investigate consumerism, debt and spending habits in the local community. Focus groups with representative age groups across the lifespan were viewed as the most appropriate data collection method to enable an inclusive, action-research orientated approach (Stake, 1995). The steering group identified five key topics for focus-group discussion: consumerism, borrowing, debt, impact of debt and getting out of debt.

Four focus groups were held with representatives of the key community constituencies - mothers, teenagers, children and older people. The mothers group was composed of five mothers who were known to a local family support service. They were between the ages of 30 and 35 years, lived with a partner, had two to four children under the age of 12 years and were each members of an extended family network. Four of the five families were dependent on statutory benefit with two of the mothers supplementing their income with part-time work. The focus group for teenagers was arranged by a local youth worker and consisted of seven young men, 17 and 18 years old. Five had left school at 16, two worked full time, three part-time and two remained in full-time education. The focus group with children took place in a local primary school and involved four boys and four girls, aged 10 years, who were selected and invited to participate by their class teacher. There was also a short discussion with a group of 11-year olds. The older people's focus group consisted of two couples and two widows who all resided in a local sheltered housing scheme, 
were dependent on state pensions and whose participation was requested by their housing manager.

Two facilitators shared the task of guiding the focus groups, one introduced the topics and prompted discussion, and the other took hand-written notes of participants' contributions. Fieldwork notes of the focus-group sessions were typed up and these transcriptions were read and reread in a process of categorical analysis (Silverman, 2005). Categories were generated from the data and the coded data assigned to relevant categories and concepts. Emerging themes were identified and checked for replication with the original data for convergence and divergence. There were five key themes: the young consumer; being a good parent; celebration and ritual; the network of credit and debt; and managing and not managing.

\section{Findings}

The five themes can be divided between the first three which describe the consumerist pressures and the two final themes which report the financial struggles and resulting threat to well-being. The experience of consumerism is a primary focus in the present study for children and teenagers and this is the subject of the first key theme - 'the young consumer'. How mothers respond to such consumerist demands from their offspring is reported in the second key theme - 'being a good mother'. It was found that conspicuous celebration is a frequent manifestation of consumerism in the local sub-culture and this experience is described in the third key theme 'celebration and ritual'. The fourth theme, 'the pattern of credit and debt', is concerned with how the financial demands of these consumerist pressures are met. The individual value placed on 'being a good manager' and the psychological and health consequences of being in debt are the topic of the final theme - 'managing and not managing'.

\section{The young consumer}

An analysis of the focus-group discussion with 10- and 11-year-old children revealed a choice of status markers which was gender-differentiated. All the girls had Barbie dolls and the boys game consoles. The girls were preoccupied with shopping for their own clothes whilst the primary concern of the boys was their replica Premiership Football Club strips. At this age, there was a movement away from toys and fantasy figures to products designed for adults with a social function and to real-life heroes. Boys identified games consoles, petrol or electric scooters, quad-bikes and football tops (the authentic brand) if not the complete kit, as one boy puts it: 'I'm addicted to football tops'. Also evident was an awareness of social identity as Catholic and Nationalist in their choice of the Celtic F.C. football strip as their prised possession.

The girls were more interested in shopping for their own clothes and possessed a developed brand awareness with an expressed desire to shop in a recently opened national chain store in the city shopping centre. Their self-perception as emerging consumers was apparent, expressed in one girl's comment: 'no girl wears clothes Mum bought'.

The group of teenagers had a long and comprehensive list of what they viewed as essential spending but, in discussion, exhibited a greater freedom from brand 
enslavement, happy to buy cheaper replica football tops from a market stall. Their 'must have' list included jewellery, mobile phones, cigarettes, alcohol, fast food, games consoles, DVDs, mopeds, driving lessons, IT training courses, gym fees and entertainment. Again, clothes were not mentioned as essential spending by the young men but their importance became apparent as vehicles for brands which act as lifestyle signifiers. For example, when queried about their choice of one pair of jeans over another the young men chose 'just the brand'. Although it was acknowledged that it was possible to get 'some good cheap stuff', certain chain stores were regarded as the antithesis of fashion, regardless of their cheaper prices. A member of the older people's focus group confirmed teenage brand compliance when he recounted how his son had complained to him: 'don't you walk beside me wearing those cheap slippers [trainers] bought in the market!'

It can be seen that consumerism is a central preoccupation in the lives of the children and teenagers interviewed. The consequences for parents are now reported.

\section{Being a good mother}

The pattern of essential consumer spending for a group of local mothers was essentially driven by their fundamental desire to fulfil their understanding of what one had to do in order to be a good mother and to be seen by others as such. As one mother puts it, reflecting the feeling of the group as a whole:

I wanted to do better for my wains, I wanted them to have things that others had. You feel rotten when you can't give to the child. I feel that I let him down when I can't get him the things he wants. (Mothers' focus group)

Within the mothers' discussion, it can be seen that parental guilt driven by a desire to do the very best for their children was a constant theme, mixed with a degree of insight and ambivalence. On the one hand, there were stories of mothers who excessively indulged their children: 'what her wains want, they get. She'll leave herself broke to get them'. On the other hand, when one mother raised the possibility that perhaps the impetus to buy these things came, not from the child but from the mother, others agreed. It is clear that there is a constant tension between the very worthwhile desire of the mother to give her child what she thinks he or she needs, and the resulting stress on her resources and well-being which these demands create.

Children's birthday parties provide key opportunities for conspicuous consumption to display the attributes of good motherhood. However, it is apparent that such expectations may cause high levels of stress and anxiety for mothers as evidenced in the following quote from another mother:

You have to have a big party. You have to get something for the child to wear. You have to get a decent present because the presents are open in front of everyone. At six years old, they want to go to the bowling alley or you can get Parky the magician at eighty pounds. There was a girl turned thirteen and her parents hired a limo for eight to ten young ones to drive around the town for an hour. I spent two hundred pounds on her birthday and six hundred pounds on Santa. I'm dreading when she gets older. (Mothers' focus group) 
Children were invited to friends' parties where parents had arranged novelty treats. Parents believed their children must give a 'good' present because presents were opened at the party in front of all the guests and were therefore highly visible. Mothers also felt a need to buy a new outfit for their child to wear to attend the party. Party invitations were reciprocated until it was the parent's turn to provide an equally extravagant and costly event. In this way, extravagant consumerism beyond the means of many individual families was perpetuated.

\section{Celebration and ritual}

What was rather striking was the key importance of spending on family and social occasions for this group of Derry mothers. All described an annual cycle of spending and debt created by a culturally specific calendar of ceremonies and celebrations reaching a peak of spending at Christmas time. These rituals served as cohesive bonds to unite the community in a celebration of their shared culture. Some of these events were universal - Christmas, Easter, Halloween; some religious - Christening, First Holy Communion and Confirmation - and others were cultural - St. Patrick's Day and the annual Feis, an Irish dancing and music competition for children and young people. For example, one mother described, the expenditure on the Christening of her first child:

When I got pregnant, we started saving for the Christening right away. And once we had a big Christening for the first, we had to be able to do the same for the three of them. Two of my sisters had done it before so we felt a pressure to do the same. (Mothers' focus group)

With less money to spend, motivated by her intention to be a good mother and not differentiate between her children, this mother had subsequently equally extravagant christening parties for her other two children which obviously caused her further financial stress.

There is a tradition of large families in Derry with the result that family events involve significant expenditure. Celebration is familial, social, visible and highly valued. But expectations are perpetually scaled up. For example, St. Patrick's Day was mentioned as a day, which is now celebrated by going out to dinner whereas previously no extra expenditure was required. Some mothers recognised that occasions such as First Holy Communion demanded unreasonable extravagance, but could not see themselves economising on such important days for their children, even if the social pressure to do so was removed:

First Communion and Confirmation is wild but I wouldn't want my wain to make her communion in a school uniform. (Mothers' focus group)

Grandparents also reported the stress of having to budget carefully for their grandchildren's Christmas and birthday presents and described how they had to buy presents for up to 20 relatives and as one woman said: 'they don't want cheap things they want the best'. It is apparent that families not only can act both as a source of emotional and social support, but also as a demand in terms of family obligations and expectations. 


\section{The pattern of credit and debt}

Attitudes to debt were age-differentiated with older people having an absolute horror of debt. But this anathema was born of long familiarity evident as they reminisced on the hardships of the past:

I don't know how I brought them up. Sure, every home in the town was raised on the Provident (money lending company). It took us years to get out of it and Thank God we're finished with it...There was a boy in this town that held the family allowance books of thirty or forty mothers. He'd be waiting outside the Post Office every Monday morning to take your money and your book. (Older people's focus group)

The older people also evidenced an awareness of the larger economic picture and how it affects individual lives:

We used to say; God Bless Duponts (a multinational company with a factory in an outer industrial estate since the sixties) because people bought homes from their wages but now the multinationals come in and stay five years - people have put their faith in them and bought houses but then they're gone. (Older people's focus group)

The nature of credit and debt was a key topic for the older people's focus group. The older people sought to budget as they had always done and none had any debt. As one said:

I make what I have do me. I couldn't sleep at night if I had debt, although the pension goes nowhere and we need more money. (Older people's focus group)

In the present study, respondents understood the meaning of debt as something that cannot really be repaid whereas a loan from the Credit Union was viewed as borrowing because the amount loaned was based on the ability to repay. This distinction between credit and debt is articulated in the following quote:

Debt is something you can't really pay - the Credit Union is not really debt. The Credit Union is the greatest thing that has happened to us. It is the heart of the town. If you are unemployed, you have no security for the banks and they don't want to know you. (Older people's focus group)

The sentiment, 'I couldn't live without the Credit Union' was similarly expressed by mothers. Mothers' use of credit also involved the use of mail order catalogues to buy durable items, mainly clothes, which they found to be good value for money. The women interviewed were capable and fully intent on providing their children with the good things of life. To achieve their aim required foresight, discipline and sacrifice:

If you stick with saving every week in the parish savings you can afford the presents, you cannot get it before Christmas. But it's not easy to save ten or twenty pounds a week. (Older people's focus group)

The pressure to get into debt was acknowledged in the mothers group in their criticism of moneylenders who called to individual homes to entice people to borrow: 
I know a girl she didn't want the two hundred pounds from the Provident. They said to her: 'Sure you have it now you may as well take it'... They come round the door and nearly force you to take it. (Mothers' focus group)

It can be seen that the Derry Credit Union is the primary source of affordable credit for the local population. Operating in an ethical manner and being non-profit making, it enables people to avoid sub-prime borrowing from moneylenders. The Parish Savings Scheme also provides a convenient and valuable opportunity for families to save small amounts for major spending occasions.

\section{Managing and not managing}

The skills of money management were highly valued and admiration was expressed for 'people at the lower end of the scale who were really good managers'. There was a pride in being a good manager on a limited income and providing a good family life, as articulated by one stay-at-home mother:

It's not being unemployed that's the issue. There's a girl who's working. . . she never gets a minute. She has three cars and three or four holidays a year. She's just working to pay and she's no better off than me...the more you have the more you spend. It's really about being a good manager and that's what people at the lower end of the scale are. (Mothers' focus group)

But the underlying stress was soon apparent when an unforeseen mishap creates a financial crisis as illustrated by this quote:

I dread the insurance coming due on the car, then sometimes the car breaks down and that's $£ 50$, and then you feel rotten if you can’t give to a child. (Mothers' focus group)

Loan repayments can be a source of great stress for people with exorbitant penalties for late repayment. One member of the mothers' group described being harassed by a moneylender when she could not keep up her repayments and the group advised her to 'pay one pound a week and they can't touch you'. A second example was provided by another mother:

I was late by one hour in my repayments one week. I had seventy pounds in late charges. . .more than I was paying out in the first place. I have to borrow from the family to go up and pay it off in small sums. (Mothers' focus group)

Members of the older people's group believed there was still a stigma attached to debt and that it remained a taboo subject for everyday conversation. Mothers felt similarly:

Nobody likes to discuss how much debt you're in - people keep it to themselves. You think everyone is debt free. (Mothers' focus group)

However, the views of the teenagers were rather more mixed; some expressed a fatalistic acceptance of the inevitability of debt together with a recognition of a 
'good' debt such as a student loan, whilst others, with the confidence of youth, were scathing of those in debt:

People are greedy and stupid. They don't understand. Give them a hundred pounds and they go off and spend and have nothing to show. (Teenagers' focus group)

As mothers control their household budgets and carry the burden of financial worries, their preoccupation with money worries exhausts them and leaves them vulnerable to poor mental and physical health and with little quality time for their children. All members of the mothers' focus group knew other mothers on antidepressants because of money worries. Also reported was the likelihood of friction between partners regarding disposal of the weekly income with frequent rows a feature of family life. In this way, being in debt pervades and undermines the fabric of family life. Members of the mothers group reported that:

If someone is in debt you can see it by looking at their face - their hair's pulled back tight and they've let themselves go. There's the worry, the tranquillisers, and the cigarettes. People smoke a lot because of worry and consequently have health worries. They're not sleeping and it's the cause of a lot of marriage break-ups. The girl next door I don't know how she does it. She's on tablets. She doesn't go out and drink. She has four children and another on the way. (Mothers' focus group)

Overindebtedness causes anxiety and stress, contributing to depression reducing selfesteem, causing insomnia increasing tiredness, withdrawal from outside activities and even self-harm. To cope with the stress, people resort to health-risk behaviours such as heavy smoking and drinking which in themselves increase debt. The cumulative effects on physical ill health may necessitate sick leave from work or even redundancy resulting in further financial difficulty and debt.

\section{Resistance}

Individual responsibility for money management is a strongly upheld value but it has been argued that global forces of credit and consumerism are powerful, overwhelming and beyond personal control. Seligman (1975) in his theory of learned helplessness has shown how, when individuals accept self-responsibility for events which are outside their control, they are likely to experience feelings of victimisation and hopelessness leading to depression. Being overindebted creates such negative psychological feelings as loss of personal control and autonomy causing mental ill health. It is therefore no surprise to read media reports that one half of heavy debtors suffers from depression (The wealthier, 2010). The Money Advice and Budgeting Service in the Republic of Ireland recognises that a money advice response should be underpinned by a holistic approach to the personal trauma of feelings of powerlessness and worthlessness (Lawless, 1996). Debt is enslavement and a restriction on freedom. Worry about debt has been identified as the strongest independent socio-economic predictor of depression in women with young children. Specific health risks may be reduced at a local level by closer links between social workers and health visitors who have contact with families and debt counselling and advice services (Reading \& Reynolds, 2001). 
The moral opprobrium of being in debt may be viewed on a continuum. At one end, there is the widespread use of credit, principally, in the form of mortgages and credit cards to fuel consumer spending. Such use of credit is viewed positively for the benefit of the economy in upholding consumer demand. However, at the other end of the continuum is the use of fringe money agencies, perpetual debt and overindebtedness which has a persistently shameful image. In one sense, it may be argued that projection of residual feelings of discomfort with high mortgages and credit-card expenditure is projected onto the poor who are categorised as spendthrift, feckless and bad managers. To suggest that such overindebtedness is caused by insufficient levels of income maintenance benefits questions the whole system of social security. Rather, it is simpler to attribute individual blame.

Such projections of shame also occur between international economies; the unprecedented levels of budget deficits in the American economy are praised as the driver of global growth whilst the international debts of Third World countries are rigorously punished by the International Monetary Fund and the World Bank. It can be seen that there are clear parallels between the economic experiences of poor communities compared with rich communities and the economic experiences of poor countries compared with rich ones. The concern has been the effects of forces which are global in their scope on the local level. In one sense, the fight to counter such forces at the local-level mirrors and imitates the efforts of the anti-consumerist movement at the international level.

At a global level, there is a need for governments to take united action, for example, by the introduction of a tax on international financial transactions, first proposed by James Tobin in 1972 at a $1 \%$ rate. Given that $\$ 900$ trillion is traded each year in foreign currency speculation, a tax of one tenth of the level Tobin advocated could yield $\$ 900$ billion a year. Such a sum could achieve real change in reducing global chronic poverty and eliminating child labour in the Third World (Tax, 2009).

We are at the mercy of global multinationals but these behemoths are not immune to strategies of ethical resistance of which they are forced to take notice (Klein, 2001). For example, the Fair Trade Organisation, which aims to tackle exploitation of workers by the payment of a decent price for their products, is now acknowledged by the major supermarkets which have begun to stock Fair Trade goods. The fact that even a multinational like Nestle, which has for over 30 years been the target of a consumer boycott because of its promotion of baby-milk formula in Third World hospitals, has now a Fair Trade product demonstrates how sensitive global business has become to its ethical image.

However, local residents are fearful of national and international professional campaigners subsuming their local issue into an anti-globalist agenda. Campaign strategies and resources can be adapted to the local setting to enable local people to maintain ownership and control. For example, to counter consumerism in the studied Derry community, anti-consumerist workshops creating fancy-dress costumes for the Haloween carnival parade and Christmas present-making sessions have been successfully organised.

There is much emphasis on the provision of education and information in the Global Justice Movement. The secondary schools' curriculum is increasingly integrating teaching on financial skills, media literacy and global issues such as the exploitation of developing countries but a case can be argued for such material to be adapted to suit the needs of younger children and teaching extended into primary 
schools. Such programmes may be more appropriately integrated into the local community setting and could raise awareness to enable young people to make choices as sophisticated and informed as the advertising directed at them.

Locally, programmes of debt management and income maximisation are an urgent requirement for mothers who are the household money managers but such programmes should be embedded within a wider planned intervention to avoid stigmatising participants. To address the negative effects of debt on individual health and well-being, personal development groups are proposed to promote self-esteem and raise self-assertiveness as a step towards increased individual capacity to resist the pressure to spend and consume. Other activities such as teaching stressmanagement skills, pioneering alternative therapies and advocating healthy nutrition, will assist in reducing health-threatening behaviours.

The Republic of Ireland is one of the few countries where the state funds a dedicated money advice service (the Money Advice and Budgeting Service with a network of 50 branches) for individuals on low incomes who have fallen victim of predatory lending. The service provides money advice and access to affordable credit by underwriting loans taken out with credit unions. Palmer and Conaty (2002) propose that the UK Government should establish such a network of centres financed through a $10 \%$ 'ethical tithe' on the savings the government has made by the electronic payment of benefits and pensions.

Political representatives must demand that government regulates the activities of the credit industry in order to provide the protection of consumer rights to borrowers. It is argued that the following policy changes should be lobbied for: the restriction of advertising aimed at children until after the 9 pm evening threshold; the requirement that consumer and credit advertising be less aggressive, particularly advertising by car dealerships directed at young men; the introduction of a statutory ceiling on interest rates; the enforcement of a Code of Practice on debt collection agencies; the extension of the role of the Financial Services Regulator to Northern Ireland; and the promotion of a campaign to increase the level of social-security benefits.

\section{Conclusion}

Community action holds open the possibility of change. It can build on the identified strengths of indigenous skills and group solidarities. However, its effectiveness is necessarily limited by policy and global practices of the international financial system and also by the social shame of debt which reduces the potential for group action and policy and global. Yet, as Atwood (2008) has pointed out, until quite recently debt was not regarded as a purely financial matter. One lent to people whose social status encouraged belief ('credit') that they were reliable. Such reciprocity binds people together in bonds of mutuality which favour status, friendship and trust rather than anonymous credit ratings. The present study has shown how communitybased organisations such as the Derry Credit Union can integrate such communal values in an effective lending agency. Communities can protect themselves from the vicissitudes of the global economy and mitigate its adverse deleterious effects by taking control in such self-help solutions. 


\section{Notes on contributor}

Roger Manktelow is a Lecturer in the School of Sociology and Applied Social Studies at the University of Ulster at Magee. His doctoral thesis was on the social construction of mental illness in psychiatric hospitalisation. Current research interests are the use of compulsion in mental health services, family burden of caring, discredited and discreditable stigma amongst individuals with enduring mental illness and the Victorian asylums in Ireland.

\section{References}

Atwood, M. (2008). Payback. Debt and the shadow side of wealth. London: Bloomsbury.

B\&HCDP. (2002). Hope for health. Targeting health and social needs survey. Derry: Author.

Bauman, Z. (1998). Work, consumerism and the new poor. Buckingham: Open University Press.

Berger, A. (2004). Shop 'till you drop'. Blue Ridge Summit, PA: Rowman \& Littlefield.

Berthoud, R. (1989). Credit, debt and poverty. London: HMSO.

Byrne, N., McCarthy, O., \& Ward, M. (2005). Meeting the credit needs of low-income groups. Credit unions versus moneylenders. Dublin: Combat Poverty Agency.

Cahill, M. (1998). Consumerism and the future of social policy. In N. Ellison \& C. Pierson (Eds.), Developments in British social policy (pp. 247-259). London: MacMillan.

Collard, S., Kempson, E., \& Dominy, N. (2003). Promoting financial inclusion. Bristol: The Policy Press.

Donnan, H., \& McFarlane, G. (1986). You get on better with your own: Social continuity and change in rural Ireland. In P. Clancy, S. Drudy, K. Lynch, \& L. O’Dowd (Eds.), Ireland: A sociological profile (pp. 380-399). Dublin: Institute of Public Administration.

Elliott, M. (2000). The Catholics of Ulster. A history. London: Penguin.

Ford, J. (1991). Consuming credit. Debt and poverty in the UK. London: Child Poverty Action Group.

Gallaher, M. (2001). What's the chances. Derry: Bogside and Brandywell Initiative/Creggan Neighbourhood Partnership.

Goldman, R., \& Papson, S. (1998). Nike culture. London: Sage.

Granovetter, M. (1973). The strength of weak ties. American Journal of Sociology, 78(6), 13601380 .

Gunter, B., \& Furnham, A. (1998). Children as consumers: A psychological analysis of the young people's market. London: Routledge.

James, O. (2008). Affluenza. London: Vermilion.

Kempson, E. (2002). Over-indebtedness in Britain. Bristol: Personal Finance Research Centre, University of Bristol.

Keohane, K., \& Kuhling, C. (2004). Collision culture. Transformations in everyday life in Ireland. Dublin: The Liffey Press.

Klein, N. (2001). No logo. London: Flamingo.

Lacey, B. (1999). Discover Derry. Dublin: O’Brien Press.

Lawless, J. (1996). The problem of debt: A counsellor's perspective. Dublin: MABS.

Mallett, J. (2002). Poverty and health - a psychological analysis (Unpublished doctoral thesis). University of Ulster at Magee, Derry.

Manktelow, R. (2007). The needs of victims of the troubles in Northern Ireland. The social work contribution. Journal of Social Work, 7(1), 31-50.

Manktelow, R., \& Lindsay, T. (2003). An evaluation of the sure start services provided by the Shantallow community support partnership. Derry: Foyle H\&SST.

Manning, R. (2002). Credit card nation. The consequences of America's addiction to credit. New York, NY: Basic Books.

McCann, E. (1984). War and an Irish town. London: Pluto.

McConnell, P., Bebbington, P., McLelland, R., Gillespie, K., \& Houghton, S. (2002). Prevalence of psychiatric disorder and the need for psychiatric care in Northern Ireland The British Journal of Psychiatry, 181(3), 214-222.

Mitchell, B. (1992). The making of Derry. An economic history. Derry: Genealogy Centre of Derry.

National Statistics Office. (2001). Social trends. No 31. London: The Stationary Office. 
Northern Ireland Association of Citizens Advice Bureaux. (2001). Would you credit it? $A$ report presenting the $C A B$ evidence in relation to debt and money advice issues in Northern Ireland. Belfast: Author.

OPEN. 2005. Do the poor pay more? A study of lone parents and debt. Dublin: One Parent Exchange and Network.

Palmer, H., \& Conaty, P. (2002). Profiting from poverty. Why debt is big business in Britain. London: New Economics Foundation.

Paterson, M. (2006). Consumption and everyday life. Abingdon: Routledge.

Powell, F., \& Geoghegan, M. (2004). The politics of community development. Dublin: Farmar Press.

Reading, R., \& Reynolds, S. (2001). Debt, social disadvantage and maternal depression. Social Sciences and Medicine, 53(4), 441-453.

Ritzer, G. (1995). Expressing America. A critique of the global credit card society. Thousand Oaks, CA: Pine Forge Press.

Schor, J. (1998). The overspent American: When buying becomes you. New York, NY: Basic Books.

Schor, J. (2004). Born to buy: The commercialised child and the new consumer culture. New York, NY: Scibnet.

Seligman, M. (1975). Helplessness. San Francisco, CA: Freeman.

Silverman, D. (2005). Doing qualitative research. London: Sage.

Stake, R.E. (1995). The art of case study research. London: Sage.

Tax on speculative trading a great way to raise billions. (2009, November 5). The Irish Times, p. 16.

The wealthier a country is the more miserable it becomes. (2010, March 14). The Observer, p. 7.

Their profit, our loss. (2006, February 25). The Guardian Weekend Section, p. 44.

Turner, G. (2008). The credit crunch, housing bubbles, globalisation and the worldwide economic crisis. London: Pluto Press.

Turner, G. (2010). No way to run an economy. London: Pluto.

Valkenburg, P., \& Cantor, J. (2001). The development of a child into a consumer. Applied Developmental Psychology, 22, 61-72.

Veblen, T. (1953). The theory of the leisured class. New York, NY: The New American Library. Whelan, C. (2006). Living in Ireland. Dublin: ESRI.

Wilkinson, R., \& Pickett, K. (2009). The spirit level: Why greater equality makes society stronger. London: Allen Lane. 